\title{
Eulogy for John Downey Slade, 9 February 2002
}

How do you begin to honour a person who has had such profound professional and personal influence on so many of us throughout the world? Like some of you who have spent time swimming through waves of disbelief, sadness, anger, and guilt, images of times with John flicker through my head, creating a visual tapestry of this truly unique man.

There is John, the Healer, who devoted his career to easing the pain of those suffering from addiction. Each of his patients treated with such compassion and dignity, while he listened so intently to each unique story. John trained countless legions of physicians and substance abuse counsellors in the USA and in far-off places, like Thailand and the Philippines.

There is John, the Tobacco Strategist. John changed forever our conceptions about nicotine, by demonstrating that smoking was not a "habit" but a powerful addiction-researching industry patents and secret documents to show the world how tobacco companies could take a plant, manipulate it, and lace it with chemicals, turning the cigarette into a lethal nicotine delivery device. His work and persistent prodding convinced President Clinton and FDA Commissioner David Kessler to regulate cigarettes.

John knew better than any of us how to use science for advocacy. He was a provocative and eloquent source for many reporters, be it the New York Times, Wall Street Journal, 60 Minutes, or the local Princeton Packet. John's mastery of tactics and creative thinking made all of us think harder and shine brighter.

Then, there is John, the Impish One, who once when I was feeling smug about something we'd done at the Robert Wood Johnson Foundation, sent me an antique set of Johnson \& Johnson promotional matchbooks-as if to say, "don't forget, your corporate ancestor promoted tobacco products too!"

Or, the time when we came upon a wonderful bistro in Paris' Left Bank, and John uncharacteristically ordered a rich calves liver dinner, saying that he would never order such a thing at home. The next night, returning there, when asked what Monsieur would like for dinner, "the calves liver" he replied, with a twinkle in his eye.

There was John, the Idealist, who no matter what the inconvenience, wouldn't stay at the fancy Washington hotels where meetings are always held, but patronised the Morrison Clark, a charmingly simple place that is the only totally smoke-free hotel in Washington.

And, we can't forget John, the Packrat, who collected more stuff than any mere mortal would think possible. But, oh, what he did with it! John has thousands of tobacco related objectsads, magazines, cigarette packs, Marlboro baby clothes and toy race cars-a collection called Trinkets and Trashthat more convincingly than any words portray the chicanery of the tobacco industry. He loaned pieces of that collection for congressional hearings, major TV news shows, and press conferences all over the USA and the world.

There is John, the Innocent, who after being warned about guarding his money, had his pocket picked on the Metro the first half hour he was in Paris.

And, there is John, the Giving Friend, who a number of years ago when our son was being operated on, somehow magically appeared in the surgical holding area to reassure a frightened little boy that he would be OK.

There is John, the Soul-mate, whose joy and love for Frances shone most brightly when she couldn't easily see it-like when she conducted Pro Musica and John would beam with bliss and pride from his balcony seat. Or, this summer, in the hospital with the stroke, when Frances hopped up on his bed, only to have John encircle her waist from behind her, and smile for the first time that day. Or, only three weeks ago, when John described Frances to a new colleague-noting what a talented pioneer she is in a profession where women struggle so to be recognised.

And, there is John, the Mentorwilling to give his time, encouragement, and best ideas to anyone who was serious about making a difference.

The happiest I ever saw John was on 10 August 1995-the day President Clinton announced that he would support FDA regulation of tobacco-something John has fought so long for. It was the President's weekly press briefing, to which outsiders are never invited. But, for this day, an exception had been made, and 30 or so of us had been invited to witness it.

Like two giddy teenagers, we were seated with Phil Lee, Joe Califano, Joe Garagiola, David Kessler, and other luminaries. During Clinton's speech, John just kept grinning at him—so much so that the President kept staring at us, as if to say "who on earth is that guy in the bowtie?"

On the train ride home to Princeton, John was the most relaxed and forthcoming that I have ever seen him. We spent two delicious hours waxing philosophical and sharing hopes and dreams. I asked John to what he attributed his amazing success, and he replied, "It is because I can work with anybody."

And that is the essence of John. A man who picked out the best things in all of us, set aside our blemishes, and interacted with us in ways that changed us, and the world, forever.

And now, John is gone. It is hard to understand. A colleague intended to give John a book by Ram Dass. Called Still here: embracing aging, changing and dying, in it Ram Dass describes how after becoming severely disabled by a stroke, he has managed to change his life, and be the richer for it. I took the book home and read it, searching for some answer about what happened to John. Listen:

"After any major "insult" as they call it, it's all too easy to see yourself as a collection of symptoms rather than as a total human being, including your spirit-and thus to become your illness. Fear is powerful and contagious, and at first I allowed myself to catch it ...Healing is not the same thing as curing after all; healing does not mean going back to the way things were before, but rather allowing what is now to move us closer to God."

John never made it down this path to healing. He chose a different path to be closer to his God.

And yet, even in this, he has left us a gift. For, in the void that his leaving us creates, there is opportunity for all of us to step forward.

To pick out and celebrate the best things about each other-to find new ways to work more closely together, so we achieve our common dreams and make a difference.

John Slade-physician, healer, strategist, soul mate, mentor, and friend. In memory of you, we can do no less.

Nancy J Kaufman,

The Robert Wood Johnson Foundation nkaufman@rwif.org 